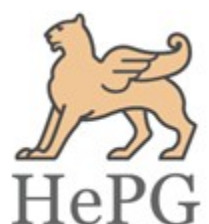

ISSN: 2348-1900

Plant Science Today

http://horizonepublishing.com/journals/index.php/PST

Research Communication

\title{
Bryophytes from the Fiji Islands, VII. Cololejeunea renneri sp. nov. (Lejeuneaceae, Marchantiophyta)
}

\author{
T. Pócs* \\ Department of Botany, Institute of Biology, Eszterházy College, Eger, Hungary, Pf 43, H-3301
}

Article history

Received: 12 August 2015

Accepted: 3 September 2015

Published online: 1 October 2015

C T. Pócs (2015)

Editor

Afroz Alam

Publisher

Horizon e-Publishing Group

Corresponding Author

T. Pócs

区

\begin{abstract}
During the biodiversity research of Fiji Islands Matt A.M Renner has collected a Cololejeunea species related to Cololejeunea filidens Benedix, widespread in the Indomalesian region, but well differs by its short, unicellular second lobular tooth and by its thin cell walls without trigones and intermediate thickenings. It is described as Cololejeunea renneri Pócs. With this the number of Cololejeunea species known from Fiji Islands raised to 43. The new species might be more widespread in the Indomalesian-Pacific region, just confused before with Cololejeunea filidens.
\end{abstract}

Keywords

Cololejeunea; Eastern Melanesia; Fiji Islands; new species; Southern Pacific

Pócs, T. 2015. Bryophytes from the Fiji Islands, VII. Cololejeunea renneri sp. Nov. (Lejeuneaceae, Marchantiophyta). Plant Science Today 2(4): 126-128. http://dx.doi.org/10.14719/pst.2015.2.4.139

\section{Introduction}

A second collecting trip was organized during August of 2011 to explore the diversity of bryoflora of the Fiji Islands by the Field Museum (Chicago), in co-operation with the South Pacific Herbarium (SPRH) of the University of the South Pacific (von Konrat et al. 2011).One of the participants, Matthew A.M. Renner from the National Herbarium of New South Wales (NSW), Australia had collected a tiny liverwort from a fallen branch in the Sovi River Valley of Viti Levu Island. Later he sent the specimen to the present author, also a participant of the expedition, responsible for the identification of the Lejeuneoideae, especially of the species of Cololejeunea. He indicated, based on literature records and his own investigations the presence of 42 species on the islands (Pócs 2012). This specimen proved to be a hitherto misunderstood representative of genus Cololejeunea and a record new to Fiji.

\section{Materials and Methods}

After careful study of the specimen and comparison with the literature records and available herbarium material it seemed that a taxon distinguished according to Tixier (1985) under the name of Cololejeunea filidens Benedix is very similar to our specimen. Both Cololejeunea filidens and our plant belong to the artificial subgenus Leptocolea (Spruce) Schiffn. (Lasiolejeunea Benedix according to Tixier) characterized by the lack of hyaline margin and larger protrusions on the cells and within it, to the Sect. Goebeliae Tixier, characterized by the presence of a filiform stylus. We had to compare Tixier's plant with the original description given by Benedix (1953). Then studied and photographed the morphological details of the Fijian specimen by a Hitachi S-2500 N type scanning electronic microscope and by a PZO SK 14 light microscope.

\section{Result and Discussion}

Investigating the original protologue and illustration given by Benedix (1953) it turned out that the specimens described and illustrated under this name by Tixier (who in fact has not seen the type of Cololejeunea filidens) are very different from the species originally described under this name. Benedix (1953) characterized Cololejeunea filidens, as 'Cellulae ... in angulis et in medio parietum conspicue noduoso-incrasatae ... Lobulus .. dente mediano bicellulari obtuso, apice subgloboso, papilla basali notato; angulari longe tricellulari hamato-filiformi (Unde nomen speciei)' (see fig. $3 \mathrm{~A}$ ). The same distinguishing 
characters are emphasized also by Gradstein (2011), stating, when keys out the Cololejeune filidens: 'Second tooth of lobule long and sharp, 3 cells long, longer than the first tooth. Cell walls with intermediate thickenings'. The plant described by Tixier (1985) under the name of Cololejeunea filidens (see fig. 3B) has the second lobule tooth much shorter than the first one, consists only of one cell and not acute and falcate. On the other hand, the first lobule tooth is longer that the second and consists mostly of two cells, just the opposite situation than by the true Cololejeunea filidens (see fig 3A). In addition, the cell walls of our plant have no large trigones and intermediate thickenings, which are usually good distinguishing characters within this genus. Furthermore, Cololejeunea filidens has 40 celled gemmae while Tixier's plant has only 20-28 celled ones. Summarizing the above, the plant collected by Matt Renner in Fiji Islands and the one distinguished under the name of Cololejeunea filidens by Tixier are identical but do not belong to that species. Therefore, a new name and description is necessary to the Fijian taxon which should be described, as a species new to science.
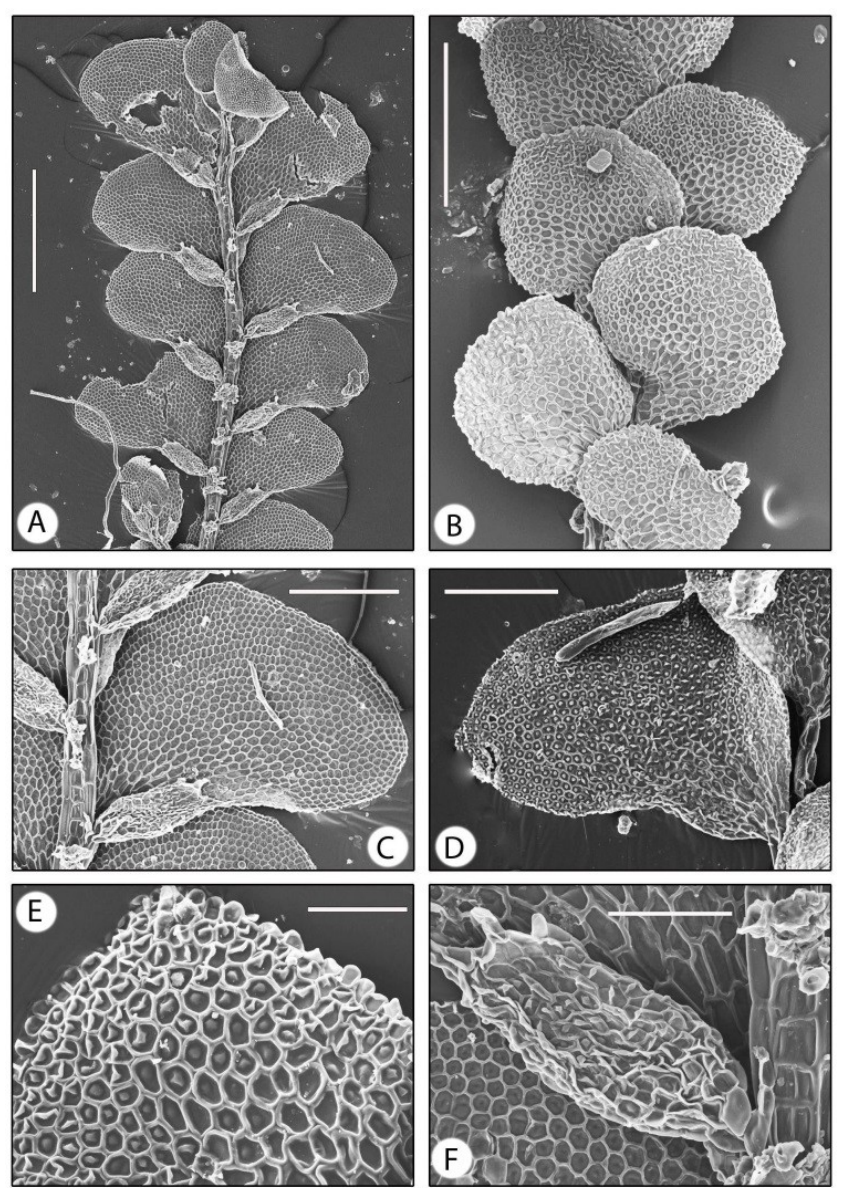

Fig 1. SEM micrographs of Cololejeunea renneri Pócs, made from the type. (A) Habit, ventral view. (B) Habit, dorsal view. (C) Leaf, ventral view. (D) Leaf, dorsal view. (E) Lobe cells, dorsal view. (F) Lobule, ventral view. Scale bars: A and B $500 \mu \mathrm{m}, \mathrm{C}$ and D $250 \mu \mathrm{m}, \mathrm{E}$ and F $100 \mu \mathrm{m}$.

Cololejeunea renneri Pócs, spec. nov. (Figs 1, 2, 3B) Syn.: Cololejeunea filidens Auct. non Benedix
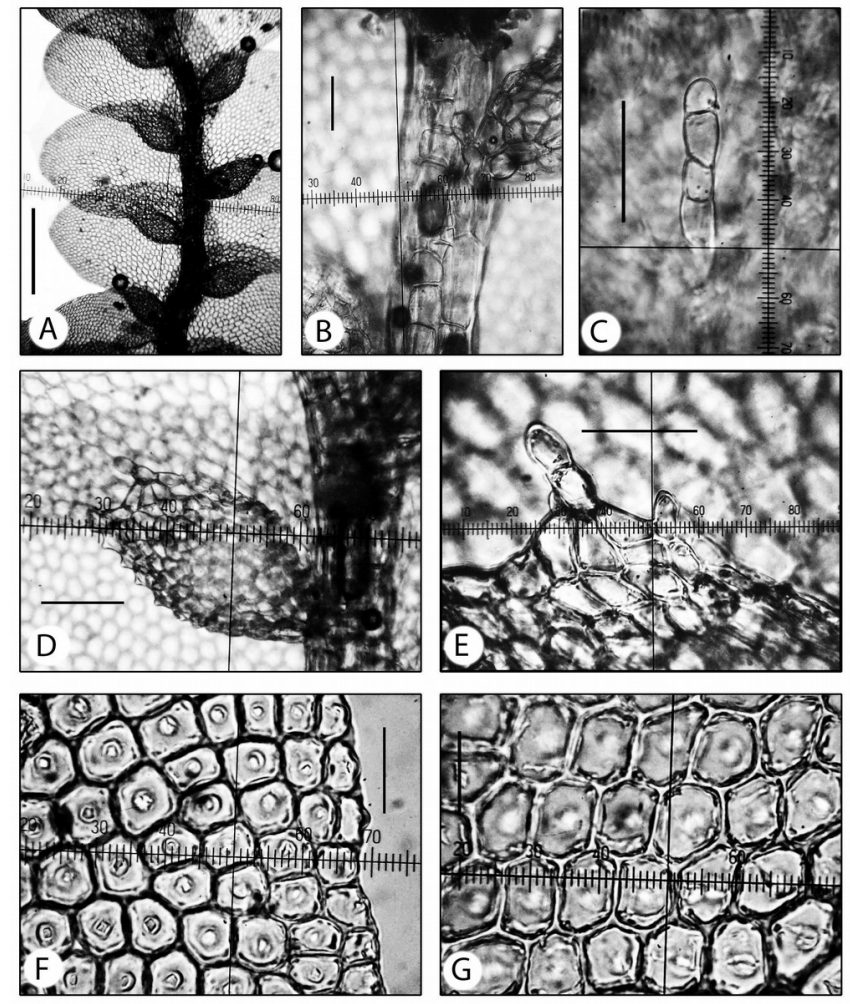

Fig 2. Light micrographs of Cololejeunea renneri Pócs, made from the type. (A) Habit, ventral view. (B) Stem with style, ventral view. (C) Style. (D) Lobule, ventral view. (E) Lobule teeth. (F) Marginal lobe cells, dorsal view. (G) Median lobe cells, ventral view. Scale bars: A: $100 \mu \mathrm{m}, \mathrm{B}$ and C $50 \mu \mathrm{m}, \mathrm{D} 100 \mu \mathrm{m}, \mathrm{E} 50 \mu \mathrm{m}, \mathrm{F}$ and G 25 $\mu \mathrm{m}$.

Diagnosis: It differs from Cololejeunea filidens Benedix, Feddes Rep. Beiheft 134: 50 and Tab. 14 (1953) by its second lobule tooth much shorter than the first and consisting only of one short triangular cell (3 cells long and acute falcate in $C$. filidens Benedix). Furthermore its lobe and lobule cell walls have no trigones and intermediate thickenings.

Type: FIJI, Viti Levu Island, Sovi Basin Natural Reserve. Below Wainiveikoka ridge in the Sovi River Valley $1.5 \mathrm{~km} \mathrm{~N}$ of Nadakuni village at altitude of 50$70 \mathrm{~m}$; S 1757'55”, E 178 $17^{\prime} 49^{\prime}$, on dead, fallen branch in disturbed secondary lowland rainforest. M.A.M. Renner \& F. Rakoro 5454, date 31 Aug. 2011. (Holotype NSW 890098, isotype EGR in microslide).

Description: In herbarium pale greenish yellow, scarcely branching plant. Shoot $8 \mathrm{~mm}$ long, 1.2-1.6 $\mathrm{mm}$ wide, stem 60-70 $\mu \mathrm{m}$ thick, ventral merophyte one cell wide. Rhizoids colorless, in small bundles below each leaf base. Leaves contiguous, inserted at $70-78^{\circ}$ to the stem, asymmetric ovate to somewhat falcate with rounded apex and smooth to crenulate margin. Lobe 640-880 x 400-540 $\mu \mathrm{m}$, each lobe cell with one round dorsal papilla. Marginal cells quadrangular, $12-15 \times 7-11 \mu \mathrm{m}$, median cell more or less isodiamtric, 18-30 $\mu \mathrm{m}$ and the basal one 25-36 $\mathrm{x}$ 10-15 $\mu \mathrm{m}$. Cell walls thin, without or with very small trigones, without intermediate thickenings. Lobule ovato-lanceolate, inflated, 200-260 x 80-160 $\mu \mathrm{m}, 0.4$ of the lobe length. First lobule tooth usually 

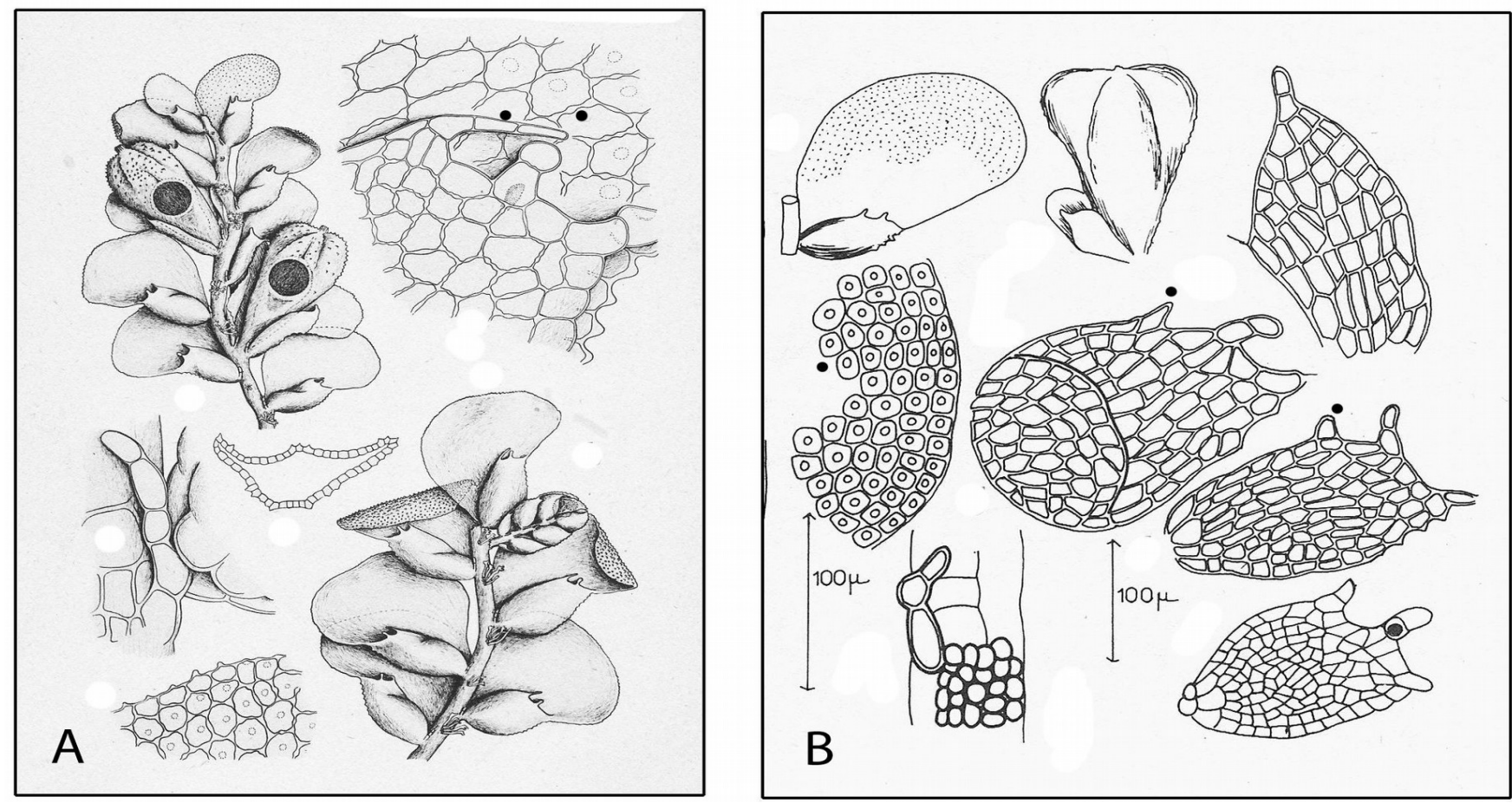

Fig 3. Comparison of the two taxa. (A) Cololejeunea filidens Benedix according to its original description and illustration (Benedix, 1953: 49 and plate 14. (B) Cololejeunea filidens according to Tixier (1985: 195 and fig. 3 on page 196). The distinguishing characters are marked by black dots.

bicellular, obtuse, with a hyaline papilla at its ental base. Second tooth much shorter than the first, unicellular, triangular. There are 1-2 marginal cells between the teeth. The lobule surface and the keel also possess papillae. Stylus filiform, 40-60 $\mu \mathrm{m}$ long, 2-4 celled, sometimes tipped by a hyaline papilla. The Fijian plant is sterile. Etymology: The species is named after its collector, Matthew A.M. Renner, bryologist of the National Herbarium of New South Wales, Australia.

The species, according to Tixier's description (under the name of Cololejeunea filidens) is dioicous, with $350 \mu \mathrm{m}$ long bracts and a $700 \times 500$ $\mu \mathrm{m}$ obpyriform perianth with a weak and broadly rounded ventral keel. He observed also100 x 60 $\mu \mathrm{m}$ large, $20-28$ celled gemmae (Tixier 1985).

Cololejeunea renneri can be distinguished from the other members of sect. Goebeliae Tixier by the combination of its papillose leaf surface and bicellular first tooth which is longer than the unicellular, triangular second tooth.

Distribution: Apart from its Fijian occurrence, judging from Tixier's account, it can be distributed from Java to Malaysia. However, he did not indicate, which specimen was illustrated in his description?

\section{Acknowledgements}

The author is grateful to Dr. Matthew A.M. Renner for placing the specimen at his disposal for study and to Dr. Krisztina Buczkó (Hungarian Natural History Museum) for assisting him in the preparation of SEM pictures.

\section{References}

Benedix E.H. 1953. IndomalayischeCololejeuneen. Eine Revision tropischer Lebermoose. Feddes Rep. spec. nov. Beih. 134: 1-88 + t. 1-31.

Gradstein S.R. 2011. Guide to the liverworts and hornworts of Java (Bogor, SEAMEO-BIOTROP).

Pócs T. 2012. Bryophytes from Fiji Islands, VI. The genus Cololejeunea Raddi (Jungermanniopsida), with the description of seven new species. Acta Bot. Hung. 54(12): $145-188$.

Tixier P. 1985. Contribution à la connaissance des Cololejeuneoideae. - Bryophyt. Bibl. 27, 1-439.

von Konrat M., Naikatini A., Tuiwawa M., Söderström L., Fife A., Renner M., Brownsey P., Perrie L., Hagborg A., Pócs T., Lumbsch H.Th., Braggins J., Séneca A. and Brown E. 2011. A brief history of the cryptogams of Fiji and prospects for the future. Telopea 13(3), 361-374. 